\title{
Synthesis and Characterization of New Lead(II) and Organotin(IV) Complexes of Schiff Bases Derived from Histidine and Methionine
}

\author{
Har Lal Singh and J. B. Singh \\ Department of Chemistry, Faculty of Engineering \& Technology, Mody Institute of Technology and Science, Lakshmangarh, \\ Rajasthan, Sikar 332311, India \\ Correspondence should be addressed to Har Lal Singh, hlsingh9@rediffmail.com
}

Received 29 November 2011; Accepted 17 January 2012

Academic Editor: Alfonso Castiñeiras

Copyright ( $) 2012$ H. L. Singh and J. B. Singh. This is an open access article distributed under the Creative Commons Attribution License, which permits unrestricted use, distribution, and reproduction in any medium, provided the original work is properly cited.

New Schiff base (HL) ligand is prepared via condensation of isatins and amino acids in 1:1 molar ratio. Metal complexes are prepared and characterized by elemental analysis, molar conductance, electronic, infrared, and multinuclear magnetic resonance $\left({ }^{1} \mathrm{H} \mathrm{NMR},{ }^{13} \mathrm{C} \mathrm{NMR}\right.$, and $\left.{ }^{119} \mathrm{Sn} \mathrm{NMR}\right)$. The analytical data showed that the ligand acts as bidentate toward metal ions via azomethine nitrogen and carboxylate oxygen by a stoichiometric reaction of metal:ligand $(1: 2)$ to from metal complexes $\left(\mathrm{Pb}(\mathrm{II})(\mathrm{L})_{2}\right.$ and $\mathrm{Bu}_{2} \mathrm{Sn}(\mathrm{L})_{2}$, where $\mathrm{L}$ is the Schiff base ligands of histidine and methionine). The conductivity values between 15 and $25 \Omega^{-1} \mathrm{~cm}^{2} \mathrm{~mol}^{-1}$ in DMF imply the presence of nonelectrolyte species. On the basis of the above spectral studies, distorted octahedral and tetrahedral geometry have been proposed for the resulting organotin(IV) and lead(II) complexes.

\section{Introduction}

Metal Schiff-base complexes have continued to play the role of one of the most important stereochemical models in main group and transition metal coordination chemistry due to their preparative accessibility, diversity, and structural variability. In recent years, a number of Schiff bases have been reported to possess significant and diverse biological activities such as antifungal, analgesic, anti-inflammatory, antibacterial, antioxidant, antitumor, local anesthetic, and antimicrobial activities [1-6]. On the other hand, radicals retard the progress of many chronic diseases such as vascular diseases, oxidative stress responsible for DNA, protein and membrane damage, and some forms of cancer $[7,8]$.

During the last few decades, metal carboxylates have been the subject of extensive investigations because of their remarkable structural diversity $[9,10]$ as well as significant biological activity, for example, pesticidal, bactericidal, and antitumor agents $[11,12]$. In continuation of recent reports from this laboratory on some amino acid Schiff base metal complex systems [13-16], the present studies, ligand $\left(\mathrm{L}^{1} \mathrm{H}-\mathrm{L}^{4} \mathrm{H}\right)$ is obtained by the condensation reaction between amino acids (L-histidine, DL-methionine) and isatin, chloroisatin with this hope that it may provide us valuable theoretical information for exploring metal-based bacteriostatic and carcinostatic pharmaceuticals with high efficacy and low toxicity. In this effort, we have also introduced an azomethine $(-\mathrm{C}=\mathrm{N}-)$ linkage with the concern that it may permit a notable variety in the remarkable chemistry and behavior of such compounds. The synthesized Schiff base derived compounds $\left(\mathrm{L}^{1} \mathrm{H}-\mathrm{L}^{4} \mathrm{H}\right)$ have been exposed to act as bidentate towards $\mathrm{Pb}$ (II) and $\mathrm{Sn}$ (IV) metal atom solely through the azomethine nitrogen and carboxylate oxygen forming a stable five-member chelate ring. The structures of the ligands are shown in Figure 1.

\section{Experimental}

All chemicals used in the present work, namely, isatin, 5chloroisatin, L-histidine, Dl-methionine, and metal acetate were of analytical grade. Solvents used were dried and purified by standard methods, and moisture was excluded 


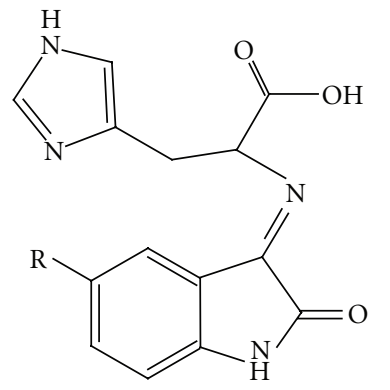<smiles>[Y]c1ccc2c(c1)/C(=N\C(C[CH]SC)C(=O)O)C(=O)N2</smiles>

$\mathrm{R}=\mathrm{H}$ and $\mathrm{CI}$

FIgURE 1: Structure of Schiff bases.

from the glass apparatus using $\mathrm{CaCl}_{2}$ drying tubes. The melting points of the compounds were determined on a capillary melting point apparatus and were not corrected. The purity of the compounds was confirmed by thin layer chromatography using silica gel-G glass plates as the stationary phase and benzene and ethanol $(9: 1)$ as the mobile phase.

2.1. Analytical Methods and Spectral Measurements. Tin and lead were determined gravimetrically as tin oxide and lead sulphate, respectively. Nitrogen and sulfur were estimated by Kjeldahl's and Messenger's methods, respectively. Molar conductance measurements were made in anhydrous dimethylformamide at $35 \pm 5^{\circ} \mathrm{C}$ using a Systronics conductivity bride model 305. Molecular weight determinations were carried out by the Rast camphor method.

The electronic spectra of the ligands and their metal complexes were recorded in dry DMSO, on a Thermoscientific, Double-beam spectrophotometer UV 1, in the range of $800-200 \mathrm{~nm}$. Multinuclear NMR spectra were recorded with a Bruker Avance-400 spectrometer $\left(400 \mathrm{MHz}\right.$ for ${ }^{1} \mathrm{H}$, $100.6 \mathrm{MHz}$ for ${ }^{13} \mathrm{C}$, and $149.2 \mathrm{MHz}$ for ${ }^{119} \mathrm{Sn}$ ) with DMSO$\mathrm{d}_{6}$ as solvent. Chemical Shifts are given ppm $(\delta)$ relative to residual DMSO signals and coupling constants $(\mathrm{J})$ are reported in hertz and with respect to reference standards (internal SiMe4 for ${ }^{1} \mathrm{H}$ NMR and ${ }^{13} \mathrm{C}$ NMR spectra and external TMT for ${ }^{119} \mathrm{Sn}$ NMR). IR spectra were obtained from a Perkin-Elmer RX1 FTIR spectrometer as KBr disks.

2.2. Preparation of the Ligands. The ligands were synthesized by the condensation of isatin ( $3.50 \mathrm{mmole}), 5$-chloroisatin (3.50 mmole), with the amino acids (3.50 mmole, histidine and methionine) in 1:1 molar ratio using methanol $(100 \mathrm{~mL})$ as the reaction medium, and then it was refluxed for 4-5 h. After this it was put on cooling at room temperature and the solid products were obtained. The excess solvent was removed on a rotary evaporator. It was further dried and then purified by recrystallization from same solvent.

3-(1H-imidazol-4-yl)-2-(2-oxoindolin-3-ylideneamino) propanoic acid $\left(\mathrm{L}^{1} \mathrm{H}\right)$ was prepared by reacting isatin with histidine: colour, dark brown; yield, $91.0 \% ; \mathrm{mp}, 110^{\circ} \mathrm{C}$ (d) and elemental analysis (\%) calcd. for $\mathrm{C}_{14} \mathrm{H}_{12} \mathrm{~N}_{4} \mathrm{O}_{3}$ : C,
59.15; H, 4.25; N, 19.71; found, C: 59.01; H, 4.22; N, 19.63; molecular weight: found, 287.84, calcd. 284.27. ${ }^{1} \mathrm{H}$ NMR $\left(\mathrm{DMSO}_{6} \mathrm{~d}_{6}, \delta \mathrm{ppm}, 400 \mathrm{MHz}\right): 12.55(\mathrm{~s}, 1 \mathrm{H}, \mathrm{COOH}), 4.61$ $(\mathrm{t}, 1 \mathrm{H}, \mathrm{N}-\mathrm{CH}-), 3.21\left(\mathrm{~d}, 2 \mathrm{H},-\mathrm{CH}_{2}\right), 7.08-7.80(\mathrm{~m}, 6 \mathrm{H}$, aromatic); ${ }^{13} \mathrm{C}$ NMR (DMSO, $\delta$ ppm): $177.4(\mathrm{COOH}) ; 54.8$ $(\mathrm{CH}), 32.6\left(\mathrm{CH}_{2}\right) ; 163.7(\mathrm{C}=\mathrm{N}) ; 156.6(\mathrm{C}=\mathrm{O}) ; 145.5,139.3$, $137.8,133.8,130.4,129.5,121.3,120.5,117.9$ (aromatic carbons); UV-visible $(\lambda \max , \mathrm{nm}): 215,265,380$; Infrared $\left(\mathrm{KBr}, \mathrm{cm}^{-1}\right): \nu(\mathrm{C}=\mathrm{N}), 1620 ; \nu(\mathrm{COOH}), 3090-2740 ; \nu(\mathrm{C}=\mathrm{O})$, $1728 ; \nu(\mathrm{NH}), 3130$.

2-(5-chloro-2-oxoindolin-3-ylideneamino)-3-(1H-imidazol-4-yl)propanoic acid $\left(\mathrm{L}^{2} \mathrm{H}\right)$ was prepared by reacting 5-chloroisatin with histidine: colour, grey; yield, 95.1\%; $\mathrm{mp}, 158-160^{\circ} \mathrm{C}(\mathrm{d})$ and elemental analysis (\%), calcd. for $\mathrm{C}_{14} \mathrm{H}_{11} \mathrm{ClN}_{4} \mathrm{O}_{3}$ : C, 52.76; H, 3.48; N, 17.58; found, C: 52.65; $\mathrm{H}, 3.46 ; \mathrm{N}, 17.67$; molecular weight: found, 325.45 , calcd. 318.72. ${ }^{1} \mathrm{H}$ NMR (DMSO- $\mathrm{d}_{6}, \delta \mathrm{ppm}, 400 \mathrm{MHz}$ ): 12.28 $(\mathrm{s}, 1 \mathrm{H}, \mathrm{COO} \underline{\mathrm{H}}), 4.45(\mathrm{t}, 1 \mathrm{H},-\mathrm{CH}-), 3.28\left(\mathrm{~d}, 2 \mathrm{H}, \mathrm{CH}_{2}\right)$ 7.12-7.82 (m, 5H, aromatic); ${ }^{13} \mathrm{C}$ NMR (DMSO, $\delta \mathrm{ppm}$ ): $178.5(\mathrm{COOH}) ; 54.7(\mathrm{CH}) ; 30.7\left(\mathrm{CH}_{2}\right) ; 162.4(\mathrm{C}=\mathrm{N}) ; 157.2$ $(\mathrm{C}=\mathrm{O}) ; 146.3,140.5,137.6,134.3,130.2,129.1,122.9,120.5$, 115.2 (aromatic carbons); UV-visible $(\lambda \max , \mathrm{nm}): 220$, 264, 385; Infrared $\left(\mathrm{KBr}, \mathrm{cm}^{-1}\right): \nu(\mathrm{C}=\mathrm{N}), 1625 ; \nu(\mathrm{COOH})$, $3100-27140 ; \nu(\mathrm{C}=\mathrm{O}), 1730, v(\mathrm{NH}), 3140$.

4-(methylthio)-2-(2-oxoindolin-3-ylideneamino)butanoic acid $\left(\mathrm{L}^{3} \mathrm{H}\right)$ was prepared by reacting isatin with methionine, colour, grey; yield, $65.12 \%$; $\mathrm{mp}, 96-110^{\circ} \mathrm{C} \mathrm{(d)} \mathrm{and}$ elemental analysis (\%), calcd. for $\mathrm{C}_{13} \mathrm{H}_{14} \mathrm{~N}_{2} \mathrm{O}_{3} \mathrm{~S}$ : C, 56.10; $\mathrm{H}, 5.07 ; \mathrm{N}, 10.06 ; \mathrm{S}, 11.52$; found, C: $56.22 ; \mathrm{H}, 5.01 ; \mathrm{N}$, 10.15; S, 11.63; molecular weight: found, 278.33, calcd. 283.18. ${ }^{1} \mathrm{H}$ NMR (DMSO- $\mathrm{d}_{6}, \delta$ ppm, $400 \mathrm{MHz}$ ): $11.74(\mathrm{~s}$, $1 \mathrm{H}, \mathrm{COOH}), 4.72(\mathrm{t}, 1 \mathrm{H}, \mathrm{N}-\mathrm{CH}-), 2.25\left(\mathrm{~m}, 4 \mathrm{H},-\mathrm{CH}_{2}-\right.$ ), $1.53\left(\mathrm{~s}, 3 \mathrm{H},-\mathrm{CH}_{3}\right), 8.05(\mathrm{~s}, 1 \mathrm{H}, \mathrm{N} \underline{\mathrm{H}}), 7.18-7.72(\mathrm{~m}, 4 \mathrm{H}$, aromatic); ${ }^{13} \mathrm{C}$ NMR (DMSO, $\left.\delta \mathrm{ppm}\right): 178.2(\mathrm{COOH}) ; 60.4$ $(\mathrm{CH}) ; 27.5,30.1\left(\mathrm{CH}_{2}\right) ; 17.6\left(\mathrm{CH}_{3}\right) ; 162.9(\mathrm{C}=\mathrm{N}) ; 157.3$ $(\mathrm{C}=\mathrm{O}) ; 144.6,136.1,132.3,128.4,122.5,116.8$ (aromatic carbons); UV-visible $(\lambda \max , \mathrm{nm}): 218,260,378$; Infrared $\left(\mathrm{KBr}, \mathrm{cm}^{-1}\right): \nu(\mathrm{C}=\mathrm{N}), 1625 ; \nu(\mathrm{COOH}), 3090-2750 ; \nu(\mathrm{C}=\mathrm{O})$, $1720, v(\mathrm{NH}), 3132$.

2-(5-chloro-2-oxoindolin-3-ylideneamino)-4-(methylthio)butanoic acid $\left(\mathrm{L}^{4} \mathrm{H}\right)$ was prepared by reacting 5 -chloroisatin with methionine: colour, brown; yield, $76.2 \%$; $\mathrm{mp}, 136-138^{\circ} \mathrm{C}(\mathrm{d})$ and elemental analysis (\%) calcd. for 
$\mathrm{C}_{13} \mathrm{H}_{13} \mathrm{ClN}_{2} \mathrm{O}_{3} \mathrm{~S}$ : C, 49.92; H, 4.19; N, 8.96; S, 10.25; found, C: $49.85 ; \mathrm{H}, 4.17 ; \mathrm{N}, 8.92 ; \mathrm{S}, 10.32$; molecular weight: found, 320.15, calcd. $312.77 .{ }^{1} \mathrm{H}$ NMR (DMSO- $\mathrm{d}_{6}, \delta \mathrm{ppm}$, $400 \mathrm{MHz}): 11.72(\mathrm{~s}, 1 \mathrm{H}, \mathrm{COO} \underline{\mathrm{H}}), 4.80\left(\mathrm{t}, 1 \mathrm{H}, \mathrm{N}-\mathrm{C} \underline{\mathrm{H}}-\mathrm{CH}_{2}-\right)$ , $2.30\left(\mathrm{~m}, 4 \mathrm{H},-\mathrm{CH}_{2}\right), 8.15(\mathrm{~s}, 1 \mathrm{H}, \mathrm{NH}), 1.73\left(\mathrm{~s}, 3 \mathrm{H}, \mathrm{CH}_{3}\right)$, 6.95-7.76 (m, 4H, aromatic); ${ }^{13} \mathrm{C} \mathrm{NMR} \mathrm{(DMSO,} \delta \mathrm{ppm}$ ): $179.2(\mathrm{COOH}) ; 60.4(\mathrm{CH}) ; 27.4,31.1\left(\mathrm{CH}_{2}\right) ; 18.1\left(\mathrm{CH}_{3}\right)$; $162.4(\mathrm{C}=\mathrm{N}) ; 156.5(\mathrm{C}=\mathrm{O}) ; 144.7,135.8,132.5,129.1,121.7$, 117.2 (aromatic carbons); UV-visible $(\lambda \max , \mathrm{nm}): 210$, 262, 384; Infrared $\left(\mathrm{KBr}, \mathrm{cm}^{-1}\right): \nu(\mathrm{C}=\mathrm{N}), 1622 ; \nu(\mathrm{COOH})$, 3110-2750; $\nu(\mathrm{C}=\mathrm{O}), 1735, v(\mathrm{NH}), 3145$.

2.3. Syntheses of Lead(II) and Organotin(IV) Complexes. The complexes were prepared under anhydrous conditions by the slow addition of a dry, hot methanol solution of the lead(II) acetate and dibutyltin oxide in 1:2 molar ratio to a solution of the Schiff bases in absolute methanol and benzene. The mixture was refluxed with constant stirring, giving a clear solution in half an hour; refluxing was then continued for 6-7 hours. The water and acetic acid librated in the reaction was removed azeotropically with solvent. Excess solvent was removed under reduced pressure, and the compound was dried under vacuum at $45 \pm 5^{\circ} \mathrm{C}$ after repeated washing with dry cyclohexane. The compounds were purified by recrystallization from the same solvent. The purity of the compounds was checked by TLC using silica gel $\mathrm{G}$ as adsorbent.

Compound $\mathrm{Pb}\left(\mathrm{L}^{1}\right)_{2}$ was prepared by reacting lead(II) acetate with ligand $\left(\mathrm{L}^{1} \mathrm{H}\right)$; colour, brown; yield, $65.6 \%$; $\mathrm{mp}$, $180^{\circ} \mathrm{C}$ and elemental analysis (\%), calcd. for $\mathrm{PbC}_{28} \mathrm{H}_{22} \mathrm{~N}_{8} \mathrm{O}_{6}$. $\mathrm{Pb}, 26.77$; C, 43.47; H, 2.87; N, 14.48; found: $\mathrm{Pb}, 26.58$; C, 43.34; H, 2.85; N, 14.37; molecular weight: found, 781.63, calcd. 773.72. Molar conductance (DMF, $10^{-3}, \Omega^{-1}, \mathrm{~mol}^{-1}$, $\left.\mathrm{cm}^{2}\right): 18.6 ;{ }^{1} \mathrm{H}$ NMR $\left(D^{2} S O-\mathrm{d}_{6}, \delta \mathrm{ppm}, 400 \mathrm{MHz}\right): 4.62(\mathrm{t}$, $1 \mathrm{H}, \mathrm{N}-\mathrm{CH}-), 3.20\left(\mathrm{~d}, 2 \mathrm{H},-\mathrm{CH}_{2}\right), 7.02-7.78(\mathrm{~m}, 6 \mathrm{H}$, aromatic); ${ }^{13} \mathrm{C}$ NMR (DMSO, $\left.\delta \mathrm{ppm}\right): 185.2(\mathrm{COO}) ; 54.5(\mathrm{CH})$, $33.1\left(\mathrm{CH}_{2}\right) ; 152.8(\mathrm{C}=\mathrm{N}) ; 156.4(\mathrm{C}=\mathrm{O}) ; 145.6,139.5,137.8$, $133.9,130.4,129.3,121.7,120.1,118.2$ (aromatic carbons); UV-visible $(\lambda \max , \mathrm{nm}): 218,262,370,350$; Infrared $(\mathrm{KBr}$, $\left.\mathrm{cm}^{-1}\right): v(\mathrm{C}=\mathrm{N}), 1610 ; \nu(\mathrm{C}=\mathrm{O}), 1725 ; v_{\text {asym }}(\mathrm{COO}), 1592$; $v_{\text {sym }}(\mathrm{COO}), 1325 ; \nu(\mathrm{Pb} \leftarrow \mathrm{N}), 440 ; \nu(\mathrm{Pb}-\mathrm{O}), 560$.

Compound $\mathrm{Pb}\left(\mathrm{L}^{2}\right)_{2}$ was prepared by reacting lead(II) acetate with ligand $\left(\mathrm{L}^{2} \mathrm{H}\right)$ : colour, light brown; yield, $74.5 \%$; $\mathrm{mp}, 230^{\circ} \mathrm{C}$ and elemental analysis (\%), calcd. for $\mathrm{PbC}_{28} \mathrm{H}_{20} \mathrm{Cl}_{2} \mathrm{~N}_{8} \mathrm{O}_{6}: \mathrm{Pb}, 24.59 ; \mathrm{C}, 39.91 ; \mathrm{H}, 2.39 ; \mathrm{N}, 13.30$; found; $\mathrm{Pb}, 24.39 ; \mathrm{C}, 39.85 ; \mathrm{H}, 2.40 ; \mathrm{N}, 13.22$; molecular weight: found, 849.72, calcd. 842.61. Molar conductance (DMF, $10^{-3}, \Omega^{-1}, \mathrm{~mol}^{-1}, \mathrm{~cm}^{2}$ ): $22.5 ;{ }^{1} \mathrm{H}$ NMR (DMSO$\left.\mathrm{d}_{6}, \delta \mathrm{ppm}\right): 4.42(\mathrm{t}, 1 \mathrm{H},-\mathrm{CH}-), 3.32\left(\mathrm{~d}, 2 \mathrm{H}, \mathrm{CH}_{2}\right) 7.10-$ $7.80\left(\mathrm{~m}, 5 \mathrm{H}\right.$, aromatic); ${ }^{13} \mathrm{C}$ NMR (DMSO, $\delta$ ppm): 185.6 (COO); $55.1(\mathrm{CH}) ; 31.3\left(\mathrm{CH}_{2}\right) ; 151.8(\mathrm{C}=\mathrm{N})$; $157.4(\mathrm{C}=\mathrm{O})$; $146.2,140.7,137.5,133.9,130.0,129.3,121.5,120.1,116.3$ (aromatic carbons); UV-visible $(\lambda \max , \mathrm{nm}): 220,255,372$, 355; Infrared $\left(\mathrm{KBr}, \mathrm{cm}^{-1}\right): \nu(\mathrm{C}=\mathrm{N}), 1608 ; \nu(\mathrm{C}=\mathrm{O}), 1728$; $v_{\text {asym }}(\mathrm{COO}), 1585 ; v_{\text {sym }}(\mathrm{COO}), 1322 ; \nu(\mathrm{Pb} \leftarrow \mathrm{N}), 445 ; \nu(\mathrm{Pb}-$ O), 560 .

Compound $\mathrm{Pb}\left(\mathrm{L}^{3}\right)_{2}$ was prepared by reacting lead(II) acetate with ligand $\left(\mathrm{L}^{3} \mathrm{H}\right)$ : colour, red; yield, 76.2\%; $\mathrm{mp}, 118^{\circ} \mathrm{C}$ and elemental analysis (\%), calcd. for $\mathrm{PbC}_{26} \mathrm{H}_{26} \mathrm{~N}_{4} \mathrm{O}_{6} \mathrm{~S}_{2}: \mathrm{Pb}, 27.20 ; \mathrm{C}, 40.99 ; \mathrm{H}, 3.44 ; \mathrm{N}, 7.35$; S, 8.42; found: $\mathrm{Pb}, 27.11, \mathrm{C}, 41.09 ; \mathrm{H}, 3.45 ; \mathrm{N}, 7.42 ; \mathrm{S}$, 8.41; molecular weight: found, 752.68, calcd. 761.84. Molar conductance (DMF, $10^{-3}, \Omega^{-1}, \mathrm{~mol}^{-1}, \mathrm{~cm}^{2}$ ): 20.10; ${ }^{1} \mathrm{H}$ NMR (DMSO- $\left.\mathrm{d}_{6}, \delta \mathrm{ppm}\right): 4.70(\mathrm{t}, 1 \mathrm{H}, \mathrm{N}-\mathrm{C} \underline{\mathrm{H}}-), 2.28$ $\left(\mathrm{m}, 4 \mathrm{H},-\mathrm{CH}_{2}-\right), 1.50\left(\mathrm{~s}, 3 \mathrm{H},-\mathrm{CH}_{3}\right), 8.06(\mathrm{~s}, 1 \mathrm{H}, \mathrm{NH})$, 7.10-7.74 (m, $4 \mathrm{H}$, aromatic); ${ }^{13} \mathrm{C}$ NMR (DMSO, $\delta \mathrm{ppm}$ ): $183.5(\mathrm{COO}) ; 60.2(\mathrm{CH}) ; 27.6,30.8\left(\mathrm{CH}_{2}\right) ; 17.5\left(\mathrm{CH}_{3}\right)$; 154.2 $(\mathrm{C}=\mathrm{N}) ; 157.1(\mathrm{C}=\mathrm{O}) ; 144.8,136.0,132.1,129.1,122.6$, 117.3 (aromatic carbons); UV-visible $(\lambda \max , \mathrm{nm}): 220,264$, 373, 345; Infrared $\left(\mathrm{KBr}, \mathrm{cm}^{-1}\right): \nu(\mathrm{C}=\mathrm{N}), 1610 ; \nu(\mathrm{C}=\mathrm{O})$, $1725 ; v_{\text {asym }}(\mathrm{COO}), 1585 ; v_{\text {sym }}(\mathrm{COO}), 1318 ; \nu(\mathrm{Pb} \leftarrow \mathrm{N}), 435$; $v(\mathrm{~Pb}-\mathrm{O}), 565$.

Compound $\mathrm{Pb}\left(\mathrm{L}^{4}\right)_{2}$ was prepared by reacting lead(II) acetate with ligand $\left(\mathrm{L}^{4} \mathrm{H}\right)$ : colour, brown; yield, $76.7 \%$; $\mathrm{mp}, 158-160^{\circ} \mathrm{C}$ and elemental analysis (\%), calcd. for $\mathrm{PbC}_{26} \mathrm{H}_{24} \mathrm{Cl}_{2} \mathrm{~N}_{4} \mathrm{O}_{6} \mathrm{~S}_{2}$ : $\mathrm{Pb}, 24.94 ; \mathrm{C}, 37.59 ; \mathrm{H}, 2.91 ; \mathrm{N}, 6.74$; S, 7.72; found: $\mathrm{Pb}, 24.82 ; \mathrm{C}, 37.30 ; \mathrm{H}, 2.88 ; \mathrm{N}, 6.65 ; \mathrm{S}$, 7.78; molecular weight: found, 846.13, calcd. 830.73. Molar conductance (DMF, $10^{-3}, \Omega^{-1}, \mathrm{~mol}^{-1}, \mathrm{~cm}^{2}$ ): $18.35 ;{ }^{1} \mathrm{H} \mathrm{NMR}$ (DMSO- $\left.\mathrm{d}_{6}, \delta \mathrm{ppm}, 400 \mathrm{MHz}\right): 4.78\left(\mathrm{t}, 1 \mathrm{H}, \mathrm{N}-\mathrm{CH}-\mathrm{CH}_{2}-\right.$ ), $2.29\left(\mathrm{~m}, 4 \mathrm{H},-\mathrm{CH}_{2}\right), 8.12(\mathrm{~s}, 1 \mathrm{H}, \mathrm{NH}), 1.70\left(\mathrm{~s}, 3 \mathrm{H}, \mathrm{CH}_{3}\right)$,

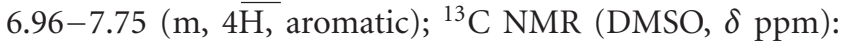
$185.3(\mathrm{COO}) ; 60.9(\mathrm{CH}) ; 27.2,31.1\left(\mathrm{CH}_{2}\right) ; 18.3\left(\mathrm{CH}_{3}\right) ; 153.8$ $(\mathrm{C}=\mathrm{N}) ; 157.2(\mathrm{C}=\mathrm{O}) ; 145.4,136.1,132.3,129.4,121.2,118.5$ (aromatic carbons); UV-visible ( $\lambda \max , \mathrm{nm}): 212,252,375$, 345; Infrared $\left(\mathrm{KBr}, \mathrm{cm}^{-1}\right): \nu(\mathrm{C}=\mathrm{N}), 1607 ; \nu(\mathrm{C}=\mathrm{O}), 1732$; $v_{\text {asym }}(\mathrm{COO}), 1580 ; v_{\text {sym }}(\mathrm{COO}), 1315 ; \nu(\mathrm{Pb} \leftarrow \mathrm{N}), 458 ; \nu(\mathrm{Pb}-$ O), 550 .

Compound $\mathrm{Bu}_{2} \mathrm{Sn}\left(\mathrm{L}^{1}\right)_{2}$ was prepared by reacting dibutyltin oxide with ligand $\left(\mathrm{L}^{1} \mathrm{H}\right)$; colour, brown; yield, $70.5 \%$; mp, $250-252^{\circ} \mathrm{C}$ and elemental analysis (\%), calcd. for $\mathrm{SnC}_{36} \mathrm{H}_{40} \mathrm{~N}_{8} \mathrm{O}_{6}$ : Sn, 14.85; C, 54.08; H, 5.04; N, 14.02; found: Sn, 14.58; C, 53.95; H, 5.01; N, 14.13; molecular weight: found, 783.68, calcd. 779.46. Molar conductance (DMF, $\left.10^{-3}, \Omega^{-1}, \mathrm{~mol}^{-1}, \mathrm{~cm}^{2}\right): 15.84 ;{ }^{1} \mathrm{H}$ NMR (DMSO- $\mathrm{d}_{6}, \delta \mathrm{ppm}$, $400 \mathrm{MHz}): 4.58$ (t, $1 \mathrm{H}, \mathrm{N}-\mathrm{C} \underline{\mathrm{H}}-), 3.24\left(\mathrm{~d}, 2 \mathrm{H},-\mathrm{CH}_{2}\right), 7.01-$ 7.76 (m, 6H, aromatic); ${ }^{13} \mathrm{C}$ NMR (DMSO, $\delta$ ppm): 183.2 $(\mathrm{COO}) ; 53.7(\mathrm{CH}), 32.8\left(\mathrm{CH}_{2}\right) ; 153.6(\mathrm{C}=\mathrm{N}) ; 156.0(\mathrm{C}=\mathrm{O})$; $144.8,139.0,137.3,133.5,130.7,129.1,121.3,120.2,118.5$ (aromatic carbons); $26.9\left(\mathrm{Sn}-\mathrm{C}-\alpha,{ }^{1} \mathrm{~J}=925 \mathrm{~Hz}\right) ; 28.1(\mathrm{Sn}-$ $\left.\mathrm{C}-\beta,{ }^{2} \mathrm{~J}=41 \mathrm{~Hz}\right) ; 27.1\left(\mathrm{Sn}-\mathrm{C}-\gamma,{ }^{3} \mathrm{~J}=126 \mathrm{~Hz}\right) ; 13.5(\mathrm{Sn}-\mathrm{C}-$ $\delta) ;{ }^{119} \mathrm{Sn}$ NMR (DMSO, $\left.\delta \mathrm{ppm}\right):-368.3$; UV-visible $(\lambda \max$, $\mathrm{nm}): 215,260,368,347$; Infrared $\left(\mathrm{KBr}, \mathrm{cm}^{-1}\right): \nu(\mathrm{C}=\mathrm{N})$, $1610 ; v(\mathrm{C}=\mathrm{O}), 1725 ; v_{\text {asym }}(\mathrm{COO}), 1592 ; v_{\text {sym }}(\mathrm{COO}), 1325$; $v(\mathrm{Sn} \leftarrow \mathrm{N}), 440 ; \nu(\mathrm{Sn}-\mathrm{O}), 562 ; \nu(\mathrm{Sn}-\mathrm{C}), 656$.

Compound $\mathrm{Bu}_{2} \mathrm{Sn}\left(\mathrm{L}^{2}\right)_{2}$ was prepared by reacting dibutyltin oxide with ligand $\left(\mathrm{L}^{2} \mathrm{H}\right)$ : colour, dark brown; yield, $68 \%$; mp, $260^{\circ} \mathrm{C}$ and elemental analysis (\%), calcd. for $\mathrm{SnC}_{36} \mathrm{H}_{40} \mathrm{Cl}_{2} \mathrm{~N}_{8} \mathrm{O}_{6}: \mathrm{Sn}, 13.67 ; \mathrm{C}, 49.79 ; \mathrm{H}, 4.41 ; \mathrm{N}, 12.90$; found; Sn, 13.52; C, 49.85; H, 4.38; N, 12.78; molecular weight: found, 868.35, calcd. 876.13. Molar conductance (DMF, $10^{-3}, \Omega^{-1}, \mathrm{~mol}^{-1}, \mathrm{~cm}^{2}$ ): 19.58; ${ }^{1} \mathrm{H}$ NMR (DMSO$\left.\mathrm{d}_{6}, \delta \mathrm{ppm}\right): 4.46(\mathrm{t}, 1 \mathrm{H},-\mathrm{C} \underline{\mathrm{H}}-), 3.30\left(\mathrm{~d}, 2 \mathrm{H}, \mathrm{CH}_{2}\right)$ 7.08-7.82 (m, 5H, aromatic); ${ }^{13} \mathrm{C}$ NMR (DMSO, $\delta$ ppm): $185.1(\mathrm{COO}) ; 54.1(\mathrm{CH}) ; 30.9\left(\mathrm{CH}_{2}\right) ; 152.5(\mathrm{C}=\mathrm{N}) ; 157.0$ $(\mathrm{C}=\mathrm{O}) ; 146.5,140.1,137.2,134.1,130.3,129.3,121.2,120.0$, 116.2 (aromatic carbons); $27.1\left(\mathrm{C}-\alpha,{ }^{1} \mathrm{~J}=920 \mathrm{~Hz}\right) ; 28.7$ 
$\left(\mathrm{C}-\beta,{ }^{2} \mathrm{~J}=42 \mathrm{~Hz}\right) ; 27.2\left(\mathrm{C}-\gamma,{ }^{3} \mathrm{~J}=125 \mathrm{~Hz}\right) ; 13.9(\mathrm{C}-\delta) ;{ }^{119} \mathrm{Sn}$ NMR (DMSO, $\delta$ ppm): -368.3 ; UV-visible $(\lambda \max , \mathrm{nm}): 218$, 250, 370, 350; Infrared $\left(\mathrm{KBr}, \mathrm{cm}^{-1}\right): \nu(\mathrm{C}=\mathrm{N}), 1608 ; \nu(\mathrm{C}=\mathrm{O})$, $1728 ; v_{\text {asym }}(\mathrm{COO}), 1585 ; v_{\text {sym }}(\mathrm{COO}), 1322 ; \nu(\mathrm{Sn} \leftarrow \mathrm{N}), 445$; $v(\mathrm{Sn}-\mathrm{O}), 565 ; \nu(\mathrm{Sn}-\mathrm{C}), 658$.

Compound $\mathrm{Bu}_{2} \mathrm{Sn}\left(\mathrm{L}^{3}\right)_{2}$ was prepared by reacting dibutyltin oxide with ligand $\left(\mathrm{L}^{3} \mathrm{H}\right)$ : colour, red; yield, $72.5 \%$; mp, $184^{\circ} \mathrm{C}$ and elemental analysis (\%), calcd. for $\mathrm{SnC}_{34} \mathrm{H}_{44} \mathrm{~N}_{4} \mathrm{O}_{6} \mathrm{~S}_{2}$ : Sn, 15.07; C, 51.85; H, 5.63; N, 7.11; S, 8.14; found: Sn, 15.19, C, 51.68; H, 6.57; N, 7.25; S, 8.23; molecular weight: found, 796.33, calcd. 787.58. Molar conductance (DMF, $10^{-3}, \Omega^{-1}, \mathrm{~mol}^{-1}, \mathrm{~cm}^{2}$ ): $21.98 ;{ }^{1} \mathrm{H} \mathrm{NMR}$ $\left(\mathrm{DMSO}_{-} \mathrm{d}_{6}, \delta \mathrm{ppm}\right): 4.42(\mathrm{t}, 1 \mathrm{H},-\mathrm{CH}-), 3.29\left(\mathrm{~d}, 2 \mathrm{H}, \mathrm{CH}_{2}\right)$ 7.05-7.75 (m, 5H, aromatic); UV-visible ( $\lambda \max , \mathrm{nm}): 220$, 264, 370, 345; Infrared $\left(\mathrm{KBr}, \mathrm{cm}^{-1}\right): v(\mathrm{C}=\mathrm{N}), 1610 ; \nu(\mathrm{C}=\mathrm{O})$, $1725 ; v_{\text {asym }}(\mathrm{COO}), 1585 ; \nu_{\text {sym }}(\mathrm{COO}), 1318 ; \nu(\mathrm{Sn} \leftarrow \mathrm{N}), 435$; $v(\mathrm{Sn}-\mathrm{O}), 544 ; \nu(\mathrm{Sn}-\mathrm{C}), 660$.

Compound $\mathrm{Bu}_{2} \mathrm{Sn}\left(\mathrm{L}^{4}\right)_{2}$ was prepared by reacting dibutyltin oxide with ligand $\left(\mathrm{L}^{4} \mathrm{H}\right)$ : colour, dark brown; yield, 78.6\%; $\mathrm{mp}, 220^{\circ} \mathrm{C}$ and elemental analysis (\%), calcd. for $\mathrm{SnC}_{34} \mathrm{H}_{42} \mathrm{Cl}_{2} \mathrm{~N}_{4} \mathrm{O}_{6} \mathrm{~S}_{2}$ : $\mathrm{Sn}, 13.86 ; \mathrm{C}, 47.68 ; \mathrm{H}, 4.94 ; \mathrm{N}$, 6.54; S, 7.49; found: Sn, 13.82; C, 47.54; H, 4.94; N, 6.63; S, 7.58; molecular weight: found, 847.83, calcd. 856.47. Molar conductance (DMF, $10^{-3}, \Omega^{-1}, \mathrm{~mol}^{-1}, \mathrm{~cm}^{2}$ ): $19.64 ;{ }^{1} \mathrm{H} \mathrm{NMR}$ $\left(\mathrm{DMSO}_{-} \mathrm{d}_{6}, \delta \mathrm{ppm}, 400 \mathrm{MHz}\right): 4.81\left(\mathrm{t}, 1 \mathrm{H}, \mathrm{N}-\mathrm{CH}-\mathrm{CH}_{2}-\right.$ ), $2.30\left(\mathrm{~m}, 4 \mathrm{H},-\mathrm{CH}_{2}\right), 8.14(\mathrm{~s}, 1 \mathrm{H}, \mathrm{NH}), 1.72\left(\mathrm{~s}, 3 \mathrm{H}, \mathrm{CH}_{3}\right)$, 6.97-7.80 (m, $4 \overline{\mathrm{H}}$, aromatic); UV-visible $(\lambda \max , \mathrm{nm}): 215$, 250, 372, 347; Infrared $\left(\mathrm{KBr}, \mathrm{cm}^{-1}\right): \nu(\mathrm{C}=\mathrm{N}), 1607 ; \nu(\mathrm{C}=\mathrm{O})$, $1732 ; v_{\text {asym }}(\mathrm{COO}), 1580 ; v_{\text {sym }}(\mathrm{COO}), 1315 ; \nu(\mathrm{Sn} \leftarrow \mathrm{N}), 558$; $v(\mathrm{Sn}-\mathrm{O}), 450 ; v(\mathrm{Sn}-\mathrm{C}), 665$.

\section{Results and Discussion}

The Schiff base (HL) and metal complexes are subjected to elemental analysis. The results of elemental analysis $(\mathrm{C}$, $\mathrm{H}$, and $\mathrm{N}$ ) with molecular formula and the melting points are presented in Section 2. The results obtained are in good agreement with those calculated for suggested formula. New metal complexes were synthesized by the reaction of dibutyltin(IV) oxide and lead(II) acetate with Schiff bases being carried out in 1:2 molar ratios using anhydrous benzene and absolute methanol in $3: 1$ ratio as solvent. These reactions proceed with the liberation of water and acetic acid, which were azeotropically removed. The scheme of the organotin(IV) and lead(II) complexes preparation is given by Scheme 1.

The above reactions were found to be quite facile and could be completed in 6-7 h of refluxing. The resulting complexes have been obtained as coloured solid which are soluble in methanol, dimethylformamide, and dimethylsulfoxide. The chelates were dissolved in DMF, and molar conductance of $10^{-3} \mathrm{M}$ of this solution at $35 \pm 5^{\circ} \mathrm{C}$ was measured. The molar conductance valves of the complexes fall in the range 15 to $25 \Omega^{-1} \mathrm{~cm}^{2} \mathrm{~mol}^{-1}$ indicating that these chelates are nonelectrolyte.

3.1. Infrared Spectra. The IR spectra of all the ligands show the absence of bands at 3250 and $1740 \mathrm{~cm}^{-1}$ due to $v\left(\mathrm{NH}_{2}\right)$ group of amino acids and $v(\mathrm{C}=\mathrm{O})$ of isatin. Instead, a new prominent band at $1625 \pm 5 \mathrm{~cm}^{-1}$ due to azomethine $v(\mathrm{C}=\mathrm{N})$ linkage appeared in all the ligands [17, 18] indicating that condensation between ketone moiety of isatin and that of amino group of amino acid has taken place resulting into the formation of the desired ligands $\left(\mathrm{L}^{1} \mathrm{H}\right)-\left(\mathrm{L}^{4} \mathrm{H}\right)$. Moreover, on comparison of the IR spectra of the ligands with their $\mathrm{Bu}_{2} \mathrm{Sn}$ (IV) and $\mathrm{Pb}$ (II) complexes showed a major shift to lower wave numbers by $10-15 \mathrm{~cm}^{-1}$ in azomethine $v(\mathrm{C}=\mathrm{N})$ at $1610 \pm 5 \mathrm{~cm}^{-1}$ suggesting the involvement of the azomethine nitrogen with the Sn(IV) and $\mathrm{Pb}$ (II) ion [19-21]. The spectra of the ligands show a broad absorption band observed in the region $3100-2560 \mathrm{~cm}^{-1}$ which is assigned to hydrogen bond $v(\mathrm{OH})$ [14]. This band disappears on complexation, suggesting the chelation of the oxygen to the metal atoms. The $v(\mathrm{COO})_{\text {asym }}$ and $v(\mathrm{COO})_{\text {sym }}$ stretching vibrations characteristic of the coordinated carboxylate anions were indicated as strong intensity bands near 1600 and $1330 \mathrm{~cm}^{-1}$, respectively [22]. The observed large separation between $v_{\text {asym }}(\mathrm{COO})$ and $v_{\text {sym }}(\mathrm{COO})$ stretching vibrations $\left[\Delta v=v_{\text {asym }}(\mathrm{COO})-v_{\text {sym }}(\mathrm{COO}) \sim 270 \mathrm{~cm}^{-1}\right]$ for carboxylate group show the bidentate nature of ligands in the complexes. However, in the case of the free ligands and complexes, a strong band present in the free carbonyl region $1740 \pm 5 \mathrm{~cm}^{-1}$ shows that in these complexes the carboxylate group is bonded to metal in a unidentate manner [23]. Appearance of a band at $3315-3350 \mathrm{~cm}^{-1}$ in the spectra of ligands has been assigned to the stretching vibrations of the $v(\mathrm{~N}-\mathrm{H})$ groups, which remains unaltered in the metal complexes, indicating its noninvolvement in coordination.

These overall data suggest that the azomethine nitrogen and carboxylate oxygen groups are involved in coordination with the $\mathrm{Bu}_{2} \mathrm{Sn}(\mathrm{IV})$ and $\mathrm{Pb}$ (II) ion in the complexes. Several new band appearing in the complexes at $\sim 460, \sim 545, \sim 660, \sim 460$, and $\sim 540 \mathrm{~cm}^{-1}$ are probably due to $v(\mathrm{Sn}-\mathrm{O})[15,24], v(\mathrm{Sn} \leftarrow \mathrm{N})[15,25], v(\mathrm{Sn}-$ C) $[15,26], \nu(\mathrm{Pb}-\mathrm{O})[13,27]$, and $\nu(\mathrm{Pb} \leftarrow \mathrm{N})[13,27]$, respectively.

3.2. Electronic Spectra. The spectra of the ligands and their metal complexes were recorded in dry DMSO. The various bands observed were assigned to interligand and charge transfer of $n-\pi^{*}$ transitions according to their energies and intensities. A band due to the $\mathrm{C}=\mathrm{N}$ chromophore in the spectrum of ligand at $\sim 380 \mathrm{~nm}\left(\pi-\pi^{*}\right.$ transition) shifts to a lower wavelength in the spectra of metal complexes and appears at $\sim 372 \mathrm{~nm}$ in the complexes. This clearly indicates the coordination of azomethine nitrogen to the metal atom. Bands at higher energies (260-265 nm and 210-220 nm) are attributed to the indole ring $\pi-\pi^{*}$ and $n-\pi^{*}$ transition. The complexes also show one bands in the region $345-358 \mathrm{~nm}$, and these may be assigned as charge transfer bands. It has been reported that the metal is capable of forming $d \pi-$ $\mathrm{p} \pi^{*}$ bonds with ligands containing nitrogen as the donor atom. The metal atom has its d orbital completely vacant, and hence $\mathrm{M}-\mathrm{N}$ bonding can take place by the acceptance of the lone pair of electrons from the nitrogen of the ligands. 


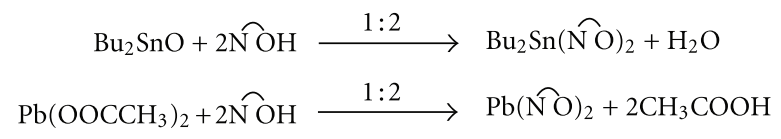

where $\mathrm{NOH}$ represents the donor system of the Schiff bases

Scheme 1: Representative equation illustrating the formation of $\mathrm{Bu}_{2} \mathrm{Sn}(\mathrm{IV})$ and $\mathrm{Pb}(\mathrm{II})$ complexes.

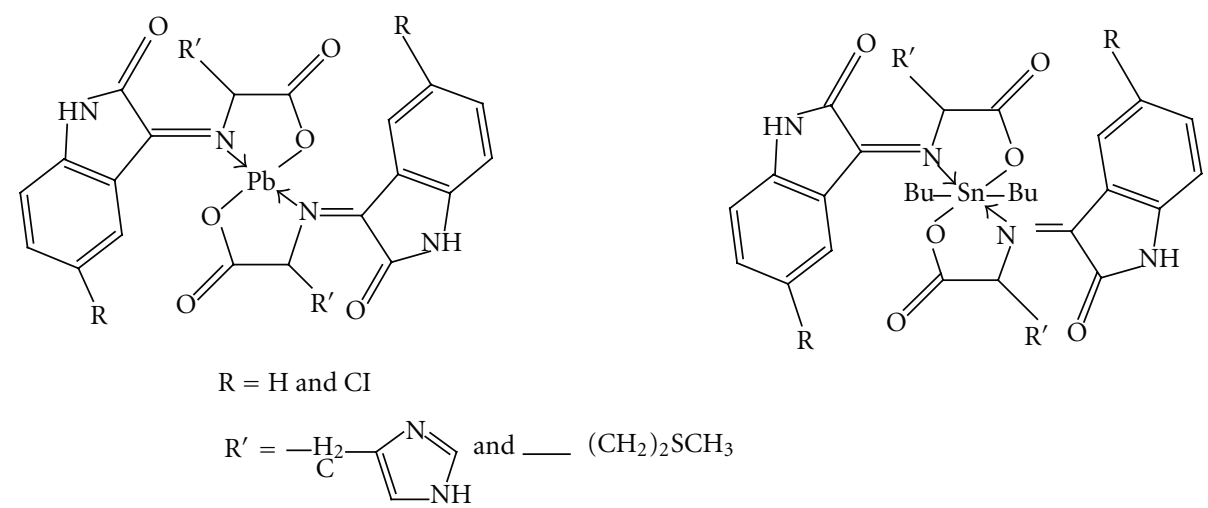

Figure 2: Proposed structure of organotin(IV) and lead(II) complexes.

3.3. ${ }^{1} H$ NMR Spectra. The characteristic resonance peaks for the synthesized compounds have been recorded in DMSO$\mathrm{d}_{6}$ and data are given in experimental section. The expected resonances are assigned by their peak multiplicity, intensity patterns, and integration. The integration peaks show good agreement with number of protons in the complexes. The ${ }^{1} \mathrm{H}$ NMR spectral data of the ligands show single resonance at $\delta 12.15 \pm 0.40 \mathrm{ppm}$, which is absent in the spectra of the complexes, indicating the replacement of the carboxylic acid proton by the organotin(IV) and lead(II) moiety. The ligands give a complex multiplet signal in the region $\delta$ $6.95-7.82 \mathrm{ppm}$ for the aromatic protons, and these remain almost at the same position in the spectra of the metal complexes. The appearance of signals due to $\mathrm{NH}$ protons at the same positions in the ligand and its complexes show the noninvolvement of this group in coordination (Figure 2).

The complexes, however, show additional signals at $\delta$ $0.72-1.90 \mathrm{ppm}$ owing to the protons of the butyl group. The $\mathrm{CH}_{2}(\alpha)$ protons of dibutyltin compounds are significant as a triplet at $0.80 \mathrm{ppm}$ with ${ }^{3} \mathrm{~J}_{\mathrm{HH}}=7.4 \mathrm{~Hz}$, while $-\mathrm{CH}_{2}-$ $\mathrm{CH}_{2}$ - protons appear as a multiplet. Terminal protons of dibutyltin(IV) also show a triplet at $0.98 \mathrm{ppm}$ with ${ }^{3} \mathrm{JHH}$ $=7.6 \mathrm{~Hz}$. The most important information obtained from ${ }^{1} \mathrm{H}$ NMR values in these compounds demonstrates that diorganotion complexes show the coordination number greater than four, probably six, in noncoordinating solvent.

3.4. ${ }^{13} \mathrm{C} N M R$ Spectra. The ${ }^{13} \mathrm{C}$ NMR spectral data for ligands and their corresponding metal complexes have been recorded in Section 2. Evidence of the formation of the complexes is clearly displayed in the ${ }^{13} \mathrm{C}$ NMR spectra. The ${ }^{13} \mathrm{C}$ NMR spectra of complexes showed the $\delta(\mathrm{COO})$ signal shifted to the downfield region which is lower compared to that of the ligand $(\sim \delta 177.8 \mathrm{ppm})$ indicating the carboxylate anion is bonded to metal atom upon complexation.

The signals due to the carbon atom attached to the azomethine group in the ligands appear at $\delta 160 \pm 2 \mathrm{ppm}$. However, in the spectra of the corresponding metal complexes, these appear at $\sim \delta 154.7 \mathrm{ppm}$. The considerable shifts in the resonance of the carbon atom attached to nitrogen indicate the involvement of azomethine nitrogen atom in coordination. The occurrence of resonances in the range of $\delta 115.5-145.8 \mathrm{ppm}$ in the ${ }^{13} \mathrm{C}$ NMR spectra of the complexes and ligand is defined as aromatic carbons signals. Generally, the ${ }^{13} \mathrm{C}$ NMR spectra of the complexes obtained were found to exhibit no additional resonances and thus reflects the purity of the complexes.

The carbon of the butyl group is observed at $(\sim \delta$ $26.6,27.8,26.0,14.3 \mathrm{ppm}$ ) position comparable to other similar compounds. The $\mathrm{R}$ group attached to tin displays resonance for chemically equivalent carbon; however, the butyl compounds display three resonances. Coordination of the tin atom has been related to ${ }^{1} \mathrm{~J}\left({ }^{119} \mathrm{Sn}-{ }^{13} \mathrm{C}\right)$ coupling constants. The ${ }^{n} \mathrm{~J}\left({ }^{119} \mathrm{Sn}-{ }^{13} \mathrm{C}\right)$ coupling constant values $(n=$ 1, $\sim 925 \mathrm{~Hz} ; n=2, \sim 40 \mathrm{~Hz} ; n=3, \sim 126 \mathrm{~Hz}$ ) obtained for the synthesized complexes are indicative of hexacoordination of dibutyltin complexes. The carbons of alkyl groups attached to tin are observed at position comparable with other similar compounds [28].

3.5. ${ }^{119} \mathrm{Sn}$ NMR Spectra. The value of $\delta\left({ }^{119} \mathrm{Sn}\right)$ defines the coordination number of the central tin atom. All the complexes, ${ }^{119}$ Sn NMR spectra, show only a sharp singlet indicating the formation of a single species. For diorganotin(IV) complexes, the $\delta\left({ }^{119} \mathrm{Sn}\right)$ value for four-coordinated complexes fall in the range between $\delta+200$ and $\delta-60 \mathrm{ppm}$, 
for five-coordinated complexes fall in the range between $\delta-90$ and $\delta-190 \mathrm{ppm}$ and for six-coordinated complexes fall in the range between $\delta-210$ and $\delta-400 \mathrm{ppm}$. Schiff base derivatives of dibutyltin(IV) exhibited $\delta\left({ }^{119} \mathrm{Sn}\right)$ values at $\sim \delta$ $-360 \mathrm{ppm}$ which lie in the range of $\delta-210$ and $\delta-400 \mathrm{ppm}$, hence indicating that the tin atom in all the complexes have six-coordinated and have a distorted octahedral geometry [29-31].

\section{Conclusion}

New Schiff base and their metal complexes have been successfully synthesized. Elemental analysis data obtained are in good agreement with the predicted formula. Distorted octahedral and tetrahedral geometries have been proposed for $1: 2$ organotin(IV) and lead(II) complexes with the help of various physicochemical studies. The infrared spectra of these complexes show the presence of monofunctional and bidentate ligands. The ${ }^{1} \mathrm{H}$ NMR spectra showed that the calculated number of protons for each functional group in the complexes is equal to the number predicted from the molecular formula. Moreover, the ${ }^{1} \mathrm{H}$ and ${ }^{13} \mathrm{C} \mathrm{NMR}$ spectra of the complexes obtained were found to exhibit no additional resonances, thus reflects the purity of the metal complexes.

\section{Acknowledgments}

The authors are thankful to the Dean, Faculty of Engineering \& Technology, Mody Institute of Technology and Science, Deemed University, Lakshmangarh, Sikar, for providing necessary facilities and financial support. They are also thankful to the Head, SAIF, Panjab University, Chandigarh, for providing elemental analysis and NMR facilities.

\section{References}

[1] I. Jarak, M. Kralj, L. Šuman et al., "Novel cyano- and $\mathrm{N}$-isopropylamidino-substituted derivatives of benzo $[b]$ thiophene-2-carboxanilides and benzo $[b]$ thieno[2,3-c] quinolones: synthesis, photochemical synthesis, crystal structure determination, and antitumor evaluation. 2," Journal of Medicinal Chemistry, vol. 48, no. 7, pp. 2346-2360, 2005.

[2] P. R. Kumar, S. Raju, P. S. Goud et al., "Synthesis and biological evaluation of thiophene [3, 2-b] pyrrole derivatives as potential anti-inflammatory agents," Bioorganic and Medicinal Chemistry, vol. 12, no. 5, pp. 1221-1230, 2004.

[3] A. D. Pillai, P. D. Rathod, F. P. Xavier, K. K. Vasu, H. Padh, and V. Sudarsanam, "Design, synthesis, and pharmacological evaluation of some 2-[4-morpholino]-3-aryl-5-substituted thiophenes as novel anti-inflammatory agents: generation of a novel anti-inflammatory pharmacophore," Bioorganic and Medicinal Chemistry, vol. 12, no. 17, pp. 4667-4671, 2004.

[4] C. K. Ryu, S. K. Lee, J. Y. Han, O. J. Jung, J. Y. Lee, and S. H. Jeong, "Synthesis and antifungal activity of 5-arylamino-4,7dioxobenzo[b] thiophenes," Bioorganic and Medicinal Chemistry Letters, vol. 15, no. 10, pp. 2617-2620, 2005.

[5] L. Pellerito and L. Nagy, "Organotin(IV)n+ complexes formed with biologically active ligands: equilibrium and structural studies, and some biological aspects," Coordination Chemistry Reviews, vol. 224, no. 1-2, pp. 111-150, 2002.

[6] K. Shahid, S. Ali, and S. Shahzadi, "The chemistry, properties, and characterization of organotin(IV)complexes of 2-(N-naphthylamido)benzoic acid," Journal of Coordination Chemistry, vol. 62, no. 17, pp. 2919-2926, 2009.

[7] I. C. F. R. Ferreira, R. P. Q. Maria-Joao, M. Vilas-Boas, L. M. Estevinho, A. Begouin, and G. Kirsch, "Evaluation of the antioxidant properties of diarylamines in the benzo[b]thiophene series by free radical scavenging activity and reducing power," Bioorganic and Medicinal Chemistry Letters, vol. 16, no. 5, pp. 1384-1387, 2006.

[8] T. Nakayama, M. Yamada, T. Osawa, and S. Kawakishi, "Suppression of active oxygen-induced cytotoxicity by flavonoids," Biochemical Pharmacology, vol. 45, no. 1, pp. 265-267, 1993.

[9] V. Chandrasekhar, K. Gopal, and P. Thilagar, "Nanodimensional organostannoxane molecular assemblies," Accounts of Chemical Research, vol. 40, no. 6, pp. 420-434, 2007.

[10] E. R. T. Tiekink, "Structural chemistry of organotin carboxylates: a review of the crystallographic literature," Applied Organometallic Chemistry, vol. 5, no. 1, pp. 1-23, 1991.

[11] M. Gielen, "Review: organotin compounds and their therapeutic potential: a report from the organometallic chemistry department of the free university of brussels," Applied Organometallic Chemistry, vol. 16, no. 9, pp. 481-494, 2002.

[12] S. K. Hadjikakou and N. Hadjiliadis, "Antiproliferative and anti-tumor activity of organotin compounds," Coordination Chemistry Reviews, vol. 253, no. 1-2, pp. 235-249, 2009.

[13] H. L. Singh, S. S. Chauhan, and H. Sachdeva, "Synthesis and characterization of $\mathrm{Pb}(\mathrm{II})$ complexes of Schiff bases derived from 3-methyl-4-fluoroacetophenone and amino acids," Research on Chemical Intermediates, vol. 36, no. 9, pp. 1037-1047, 2010.

[14] H. L. Singh, "Synthesis and characterization of tin(II) complexes of fluorinated Schiff bases derived from amino acids," Spectrochimica Acta A, vol. 76, no. 2, pp. 253-258, 2010.

[15] H. L. Singh, M. Sharma, and A. K. Varshney, "Studies on coordination compounds of organotin(IV) with schiff bases of amino acids," Synthesis and Reactivity in Inorganic and MetalOrganic Chemistry, vol. 30, pp. 445-456, 2000.

[16] H. L. Singh, M. Sharma, M. K. Gupta, and A. K. Varshney, "Coordination behaviour of biologically active Schiff bases of amino acids towards stannous Ion," Bulletin of the Polish Academy of Sciences, vol. 47, no. 2, pp. 103-110, 1999.

[17] H. I. Beltran, L. S. Z. Rivera, T. Mancilla, R. Santillan, and N. Farfan, "One-step preparation, structural assignment, and x-ray study of 2,2-di-n-butyl- and 2,2-diphenyl-6-aza-1,3dioxa-2-stannabenzocyclononen-4-ones derived from amino acids," Chemistry, vol. 9, no. 10, pp. 2291-2306, 2003.

[18] H. D. Yin, M. Hong, Q. B. Wang, S. C. Xue, and D. Q. Wang, "Synthesis and structural characterization of diorganotin(IV) esters with pyruvic acid isonicotinyl hydrazone and pyruvic acid salicylhydrazone Schiff bases," Journal of Organometallic Chemistry, vol. 690, no. 6, pp. 1669-1676, 2005.

[19] H. L. Singh and A. K. Varshney, "Synthesis and spectral studies of organotin(IV) complexes with bifunctional tetradentate Schiff bases," Main Group Metal Chemistry, vol. 22, no. 9, pp. 529-532, 1999.

[20] D. Maity, S. Chattopadhyay, A. Ghosh, M. G. B. Drew, and G. Mukhopadhyay, "Syntheses, characterization and X-ray crystal structures of a mono-and a penta-nuclear nickel(II) complex with oximato Schiff base ligands," Inorganica Chimica Acta, vol. 365, no. 1, pp. 25-31, 2011. 
[21] N. S. Gupta, M. Mohan, N. K. Jha, and W. E. Antholine, "Magnetic and mössbauer characterization of the discontinuous high-spin $\left({ }^{6} \mathrm{~A}_{1}\right) \rightleftarrows$ low-spin $\left({ }^{2} \mathrm{~T}_{2}\right)$ transition in solid bis(pyridoxal 4-phenylthiosemicarbazonato)iron(III) chloride," Inorganica Chimica Acta, vol. 184, no. 1, pp. 13-21, 1991.

[22] Q. Xie, Z. Yang, and L. Jiang, "Preparation, structure and biological activities of mixed methyldicyclohexyltin carboxylates," Main Group Metal Chemistry, vol. 19, no. 8, pp. 509-520, 1996.

[23] Y. F. Win, T. S. T. Muhammad, S. T. Ha, Y. Sivasothy, and S. G. Teoh, "Synthesis and structural characterization of organotin (IV) complexes derived of 4- (Diethylamino) benzoic acid: cytotoxic assay on human liver carcinoma cells (HepG2)," Australian Journal of Basic and Applied Sciences, vol. 4, no. 6, pp. 1383-1390, 2010.

[24] M. A. Choudhary, M. Mazhar, S. Ali, U. Salma, S. Ashraf, and A. Malik, "Synthesis, characterization and biological activity of triorganotin carboxylates containing germanium," Turkish Journal of Chemistry, vol. 26, no. 1, pp. 125-131, 2002.

[25] M. Nath, H. Singh, G. Eng, X. Song, and A. Kumar, "Syntheses, characterization and biological activity of diorganotin(IV) derivatives of 2-amino-6-hydroxypurine (guanine)," Inorganic Chemistry Communications, vol. 12, no. 10, pp. 1049-1052, 2009.

[26] B. S. Saraswat, G. Srivastava, and R. C. Mehrotra, "Schiff base complexes of organotin(IV): infrared and mössbauer studies on the addition complexes of $N$-alkyl(aryl)salicylideneimines," Journal of Organometallic Chemistry, vol. 164, no. 2, pp. 153-158, 1979.

[27] H. L. Singh, "Synthesis, spectroscopic characterization, and 3D molecular modeling of lead(II) complexes of unsymmetrical tetradentate Schiff-base ligands," Advances in Physical Chemistry, vol. 37, no. 8, pp. 1087-1101, 2011.

[28] L. L. Yeap and S. G. Teoh, "Synthesis, spectral characterization and X-ray crystal structure of some triphenyltin(IV) carboxylate compounds," Journal of Coordination Chemistry, vol. 56, no. 8, pp. 701-708, 2003.

[29] R. V. Singh, S. C. Joshi, A. Gajraj, and P. Nagpal, "Studies of biologically potent organotin(IV) and organosilicon(IV) complexes of a sulfur donor ligand derived from 1-acetylferrocene," Applied Organometallic Chemistry, vol. 16, no. 12, pp. 713-720, 2002.

[30] J. Holeček, M. Nádvorník, K. Handlír, and A. Lyčka, " ${ }^{13} \mathrm{C}$ and ${ }^{119}$ Sn NMR spectra of Di-n-butyltin(IV) compounds," Journal of Organometallic Chemistry, vol. 315, no. 3, pp. 299-308, 1986.

[31] H. L. Singh, "Synthesis, spectral, and 3D molecular modeling of tin(ii) and organotin(iv) complexes of biologically active schiff bases having nitrogen and sulfur donor ligands," Phosphorus, Sulfur and Silicon and the Related Elements, vol. 184, no. 7, pp. 1768-1778, 2009. 


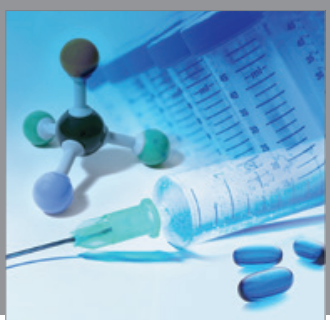

International Journal of

Medicinal Chemistry

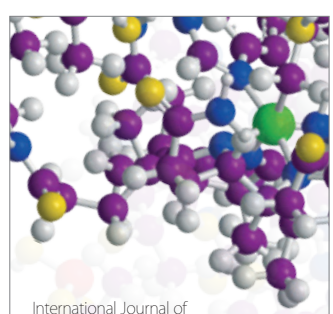

Carbohydrate Chemistry

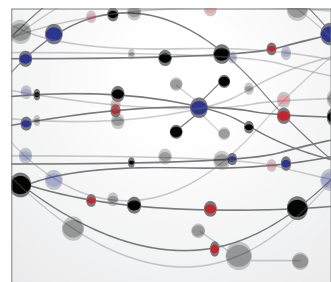

The Scientific World Journal
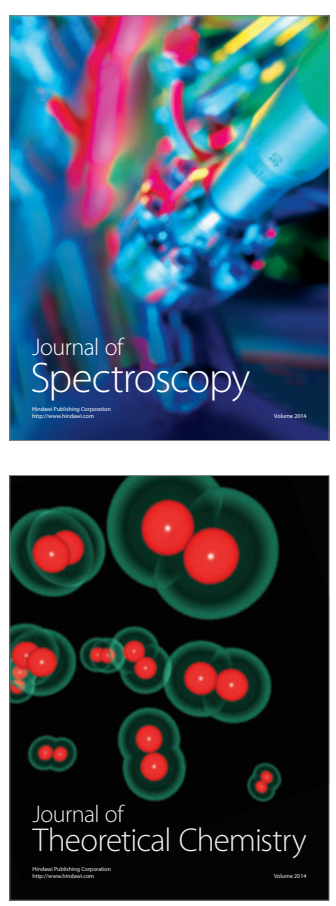
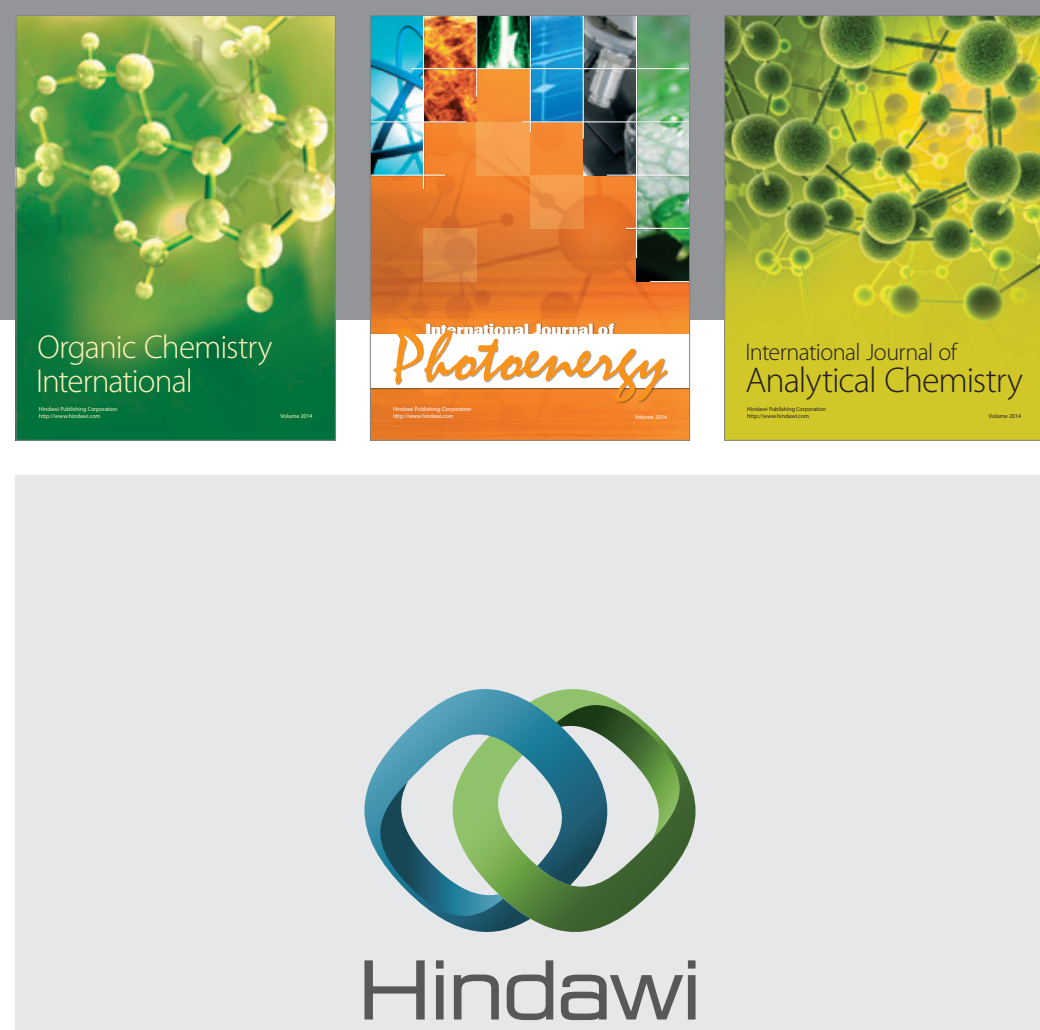

Submit your manuscripts at

http://www.hindawi.com
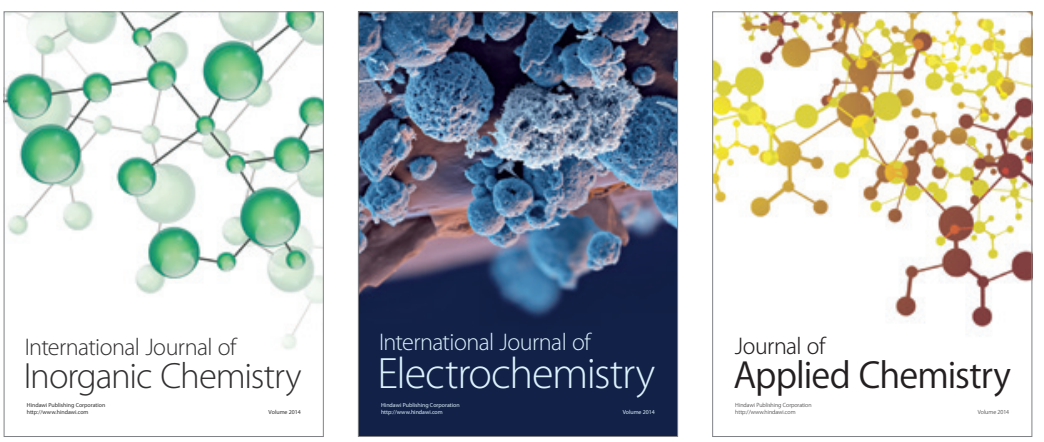

Journal of

Applied Chemistry
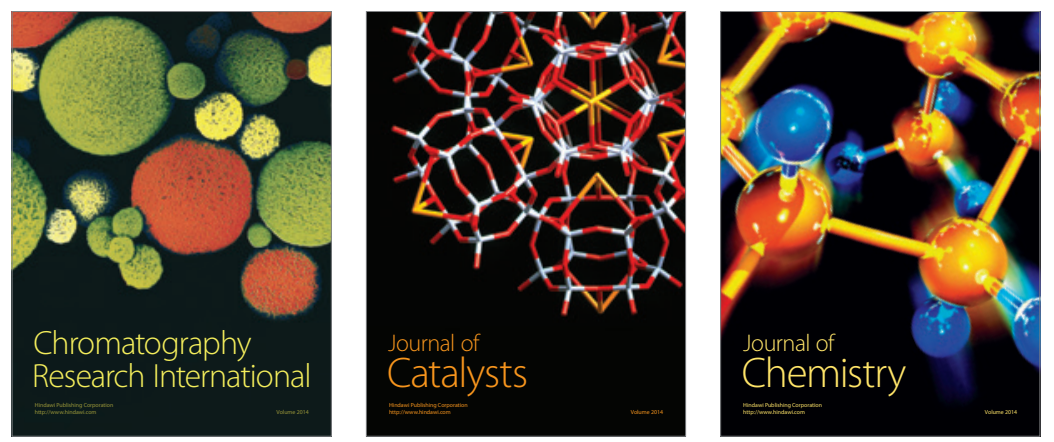
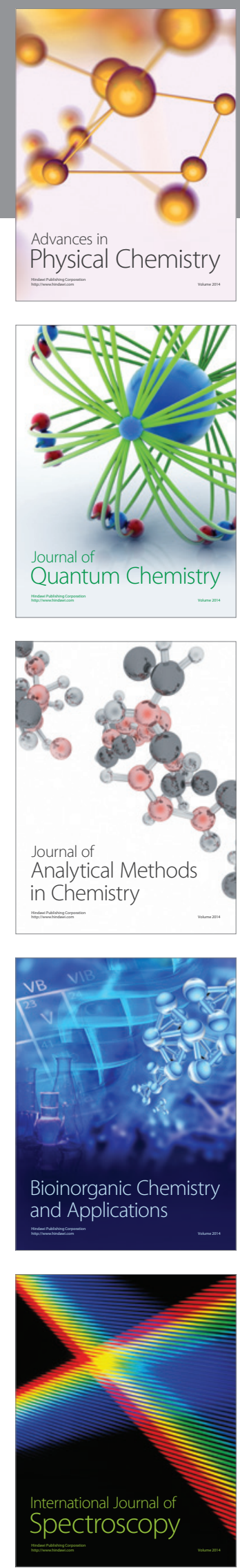